\title{
Effect of Micotoxins Treatment on Oxidative Stress, Memory and Anxious Behavior in Zebrafish (Danio rerio)
}

\author{
ELENA TODIRASCU CIORNEA ${ }^{1}$, GABRIELA DUMITRU ${ }^{1 *}$, DRAGOMIR COPREAN², TIGRAN LUCIAN MANDALIAN², \\ RAZVAN STEFAN BOIANGIU ${ }^{1}$, ION SANDU ${ }^{3,4}$, LUCIAN HRITCU ${ }^{1}$ \\ ${ }^{1}$ Alexandru Ioan Cuza University of lasi, Faculty of Biology, Department of Biology, 11 Carol I Blvd., 700506, Iasi, Romania \\ 2 University Ovidius of Constanta, Faculty of Natural Sciences and Agricultural Sciences, 1 Alley of the University, 900470 \\ ,Constanta, Romania \\ ${ }^{3}$ Alexandru Ioan Cuza University of lasi, Faculty of Geography and Geology, 11 Carol I Blvd., 700506, lasi, Romania \\ ${ }^{4}$ Romanian Inventors Forum, 3 Sf. Petru Movila Str., BI. L11, III/3, 700089, Iasi, Romania
}

\begin{abstract}
Natural contaminants, especially mycotoxins, pose a challenge since they are found in a wide range of agricultural crops and differ significantly in chemical structure and symptomatology in humans and signs of disease in animals following exposure to these chemical agents. Mycotoxins are toxic metabolites produced by a diverse group of fungi that contaminate agricultural crops prior to harvest or during storage post-harvest and different species including humans, poultry, swine and fish. Food contamination by mycotoxins is a risk to human and animal health being responsible for significant economic losses and can exhibit a broad range of effects including carcinogenicity, neurotoxicity and developmental toxicity. In the present paper was tested the influence of patulin (PAT, 70 $\mathrm{g} / \mathrm{L}$ ) and kojic acid (KA, 100, 204 and $284 \mathrm{mg} / \mathrm{L}$ ) on the activity of antioxidant enzymes (CAT and GPX), MDA (lipid peroxidation marker) but also on memory and anxious behavior in the Danio rerio experimental model.
\end{abstract}

Keywords: patulin, kojic acid, memory, behaviour, oxidative stress, zebrafish

Mycotoxins are secondary metabolites of various molds presenting a health hazard for humans and animals, the literature data showing the frequent presence of these substances worldwide in a variety of products for human and animal consumption [1-4].

Patulin - PAT (4-hydroxy-4H-furo[3,2c] pyran-2[6H]-one) is a mycotoxin produced by several Penicillium, Aspergillus and Byssochlamys species [5] which is found in significant concentrations in ripe apples, but also in other fruits such as pears, oranges and grapes [6] and contaminates fruit and vegetable products, especially apple juice and cider [7-9].

This mycotoxin, initially considered as having antibiotic properties [4], exerts toxic effects, produces chromosomal disasters and possible carcinogenicity $[10,11]$, inducing alteration of gastro-intestinal functions, but also various pathological changes in nephron [12, 13]. In the studies on the field PAT is considered to be embryogenic, mutagenic and teratogenic [14-16], induces developmental and reproductive toxicity and immunotoxicity [17, 18], acting on covalent bonds in cellular nucleophiles, especially on the thiol groups of proteins and glutathione [19-21].

The literature data, also, highlights an electrophilic reactivity of PAT leading to the formation of covalent adducts following interaction with electrophilic chemical agents, PAT intoxication leading to rapid degradation of glutathione, both in vivo and in vitro [22, 23]. Mycotoxin interacts, in the same time, with cysteine, lysine and histidine residues from the peptides and proteins, the most damaging effects of PAT treatment due to the formation of these complexes [24, 25].

Kojic acid - KA (5-hydroxy-2-(hydroxymethyl) -4-pyrone) is a fungal metabolite produced by Aspergillus, Penicillium and Acetobacter species [26] and it is widely utilized in cosmetics and pharmaceutics industry as a skin-lightening [27] due to its depigmentation activity, as well as as a food additive to prevent food browning [28].
Literature data [29] suggest an antimelanogenic effect of KA involving keratinocytes, the mechanism by which this natural product interferes in the interaction between keratinocytes and melanocytes being not fully elucidated. At the same time, KA has a multitude of other biological properties including antioxidantcapacity, antitumor activity, potent tyrosine-inhibition properties [30, 31], as well as the ability to act on immune cells, including neutrophils and macrophages cells [32]. Also, are recognized the effects of this metabolite on Leishmania amazonensis species, both in vivo and in vitro, the ability of KA to cause the death of this species due to the massive accumulation of reactive oxygen species (ROS) as a result of immunomodulation and proinflammatory cytokines induction [33, 34].

The purpose of this study was to test the biochemical and physiological response of Danio rerio to the application of PAT at concentrations of $70 \mathrm{ig} / \mathrm{L}$ and $\mathrm{KA}$ at concentrations of 100, 204 and $284 \mathrm{mg} / \mathrm{L}$.

\section{Experimental part}

Drug administration

PAT $(70 \mu \mathrm{g} / \mathrm{L})$ and $\mathrm{KA}(100 \mathrm{mg} / \mathrm{L}, 204 \mathrm{mg} / \mathrm{L}$, and 284 $\mathrm{mg} / \mathrm{L}$ ) were administered by immersion to zebrafish once daily for 7 days period before the behavior testing.<smiles>O=C1C=C2C(=CCOC2O)O1</smiles>

Fig. 1. Chemical structure of PAT<smiles>O=c1cc(CO)occ1O</smiles>

Fig. 2. Chemical structure of $\mathrm{KA}$

\section{Methods}

The activity of catalase (CAT) was determined by the Sinha spectrophotometric method, glutathione-peroxidase (GPX) by the Fukuzawa and Tokumura method by 
spectrophotometric dosing of the resulting compound following the reaction between reduced excess glutathione after reaction with hydrogen peroxide, with 5,5'-ditiobis-2nitrobenzoic acid, and the concentration of malondialdenide (MDA) by the 2-thiobarbituric acid method, adapted according to Dobrian et al., 2001 [35-38].

\section{Behavioral tasks}

In our studies, a Logitech HD Webcam C922 Pro Stream camera recorded zebrafish behavior, and the videos analyzed using ANY-maze ${ }^{\circledR}$ software (Stoelting CO, USA).

\section{Novel tank diving test (NTT, anxiety test)}

The position (bottom $x$ upper levels) was considered an index of anxiety, similar to the position near the wall versus the center of an open field with rodents [39]. Fish were transferred individually to a test aquarium ( $24 \times 8 \times 20 \mathrm{~cm}$; width $\times$ depth $\times$ height) and filmed for $6 \mathrm{~min}$. The following parameters were analyzed: (i) total distance traveled ( $\mathrm{m}$ ); (ii) entries in the upper zone of the tank; and (iii) immobility time (s).

\section{Y-maze test (memory test)}

The Y-maze test was used to asses spatial memory in zebrafish like rodents [40]. Each fish was tested individually during 5 min session [41] and the percent spontaneous alternation and the locomotor activity (the number of arm entries) was recorded.

\section{Results and discussions}

Zebrafish is a freshwater vertebrate fish belonging to the Cyprinidae family, whose popular name derives from the longitudinal pigmented stripes throughout its body. This species is often used as an experimental model for studies on vertebrate development, biology of development, genetic diseases, various toxicity tests etc. due to the rapid growth rate, the high regeneration capacity, the short maturation time, high productivity, low maintenance costs [13, 42-43].

Mycotoxins are secondary metabolites produced by a wide range of fungi [44] (Penicillium, Aspergillus, Acetobacter, Byssochlamys, Fusarium, Alternaria, Phomopsis, Emericella, Cephalosporium, Myrothecium, Trichoderma, Trichothecium, Neopetromyces, Neotyphodium, Claviceps etc.) that contaminate agricultural crops and aquatic environments, affecting various species such as pigs, poultry, human organisms and different fish species, at the lost ones, the mortality and morbidity rates being more or less high and, at the same time, strictly dependent on the concentration and type of mycotoxin present, as well as the time of the exposure time to it [45, 46].

Between the multiple effects of mycotoxins on cells, a special place occupies the accumulation of free radicals, the literature data highlighting the prioritization of studies on the relationship between the presence of mycotoxins and the decrease in cellular proliferation and the occurrence of oxidative stress due to the increase of intracellular production of reactive oxygen species and, implicitly, of the lipid peroxidation level [47, 48].

It is known that, under physiological-normal conditions, ROS production is counterbalanced by their rate of elimination, animal and vegetal organisms possessing finetuning mechanisms for the level of free radicals (including superoxide radicals, hydroxyl radicals and non-radicals of $\mathrm{H}_{2} \mathrm{O}_{2}$ type), through the endogenous cellular antioxidants such as SOD, CAT, GPX, GSH (reduced glutathione), as by other non-enzymatic antioxidants [49].
The CAT activity, a hemoprotein of the oxidoreductases class, varied from one experimental lot to another, in close correlation with the nature and concentration of the applied agent (fig. 1). Thus, if in the control group the enzyme had an average activity level of $15.956 \pm 0.918 \mathrm{U} / \mathrm{mg}$ of protein in the variant treated with PAT in a concentration of $70 \mu \mathrm{g} /$ $L$, activity decreased to less than half of the reference value (7.226 $\pm 0.423 / \mathrm{mg}$ protein), while in the experimental group to which KA was added in a concentration of $100 \mathrm{mg} / \mathrm{L}$, an average activity threshold of $12.258 \pm 0.658 \mathrm{U} / \mathrm{mg}$ protein was achieved.

In contrast, in the KA treated group in a concentration of $204 \mathrm{mg} / \mathrm{L}$, CAT exhibited a peak activity value (18.357 $\pm 0.981 \mathrm{U} / \mathrm{mg}$ protein), while at the variant containing the maximum concentration of KA $(284 \mathrm{mg} /$ $L$ ), the enzymatic activity was slightly above the control (16.258 $1.002 \mathrm{U} / \mathrm{mg}$ protein). The activity differences between the experimental variants and the reference group could be explained by the fact that, under pathological conditions generated by the presence of mycotoxins, ROS accumulate in concentrations that could not be controlled by the usual protective cellular mechanisms, which leads to the installation of the oxidative stress and, implicitly, a high level of lipid peroxidation, thing indicated, also, by some studies in the field [50].

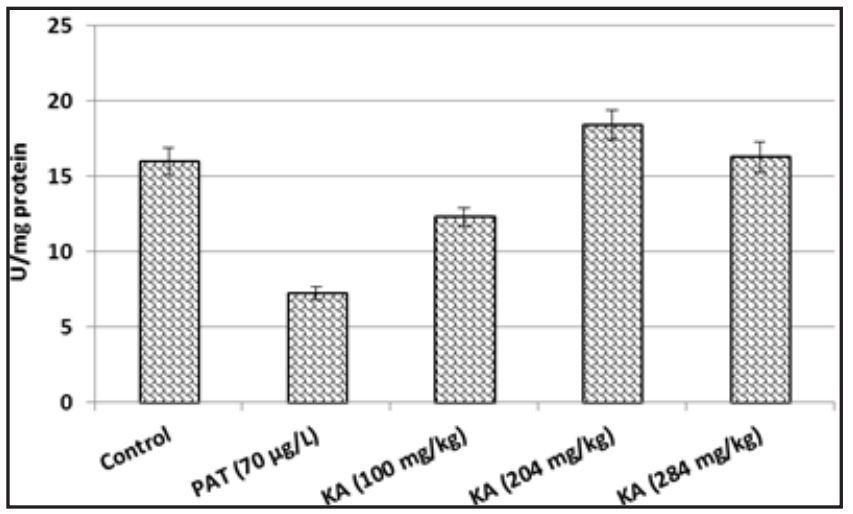

Fig. 3. CAT activity in Danio rerio treated with PAT and KA

PAT is mycotoxin from the group 3 (not classifiable as its carcinogenicity to humans) with various cytotoxic effects, among which we can mention the depletion of glutathione, which leads to an increased ROS production and the installation of oxidative disaster [4].

In our samples, GPX displayed a wide range of values, as can be seen from the figure 4 . Thus, in the control group the enzyme exhibits an average activity of $0.175 \pm 0.0068$ $\mathrm{U} / \mathrm{mg}$ of protein, and in the PAT treated variant, respectively KA in concentration of 100 and $204 \mathrm{mg} / \mathrm{L}$ respectively, GPX has a decreasing activity trend with mean values of $0.113 \pm 0.009 \mathrm{U} / \mathrm{mg}$ protein (in PAT variant), of $0.097 \pm 0.0084 \mathrm{U} / \mathrm{mg}$ protein in the samples treated with $\mathrm{KA}$ in concentration of $100 \mathrm{mg} / \mathrm{L}$, respectively of $0.146 \pm 0.0076 \mathrm{U} / \mathrm{mg}$ protein in the variant containing 204 $\mathrm{mg} / \mathrm{L} \mathrm{KA}$.

Our results are consistent with those in the literature data [51], which reveals differences in the activity of antioxidant enzymes (GPX, CAT, SOD) between the experimental variants and the reference group, suggesting that under stress the animals organisms are able to increase the production of GPX for to remove the excess of hydrogen peroxide generated by the dismutation of the superoxide radical.

Lipid peroxidation is one of the metabolic processes involved in reducing cell viability, a phenomenon due to the presence of mycotoxins, knowing that MDA and ROS have cytotoxic effects [4]. 


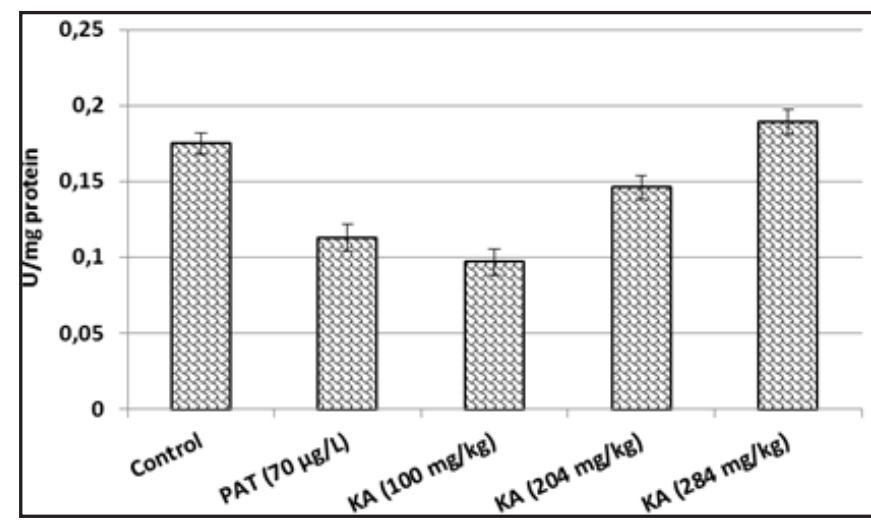

Fig. 4. GPX activity in Danio rerio treated with PAT and KA

If, in the reference variant, the MDA concentration recorded the minimum level of $0.658 \pm 0.023 \mathrm{nmol} / \mathrm{mg}$ protein (fig. 5), in treated batches with PAT $(70 \mu \mathrm{g} / \mathrm{L})$ and $\mathrm{KA}(100 \mathrm{mg} / \mathrm{L})$ this marker of lipid peroxidation reaches a mean concentration level of $0.973 \pm 0.044 \mathrm{nmol} / \mathrm{mg}$ protein respectively, $0.956 \pm 0.042 \mathrm{nmol} / \mathrm{mg}$ protein. In the case of samples containing the maximum concentration of $\mathrm{KA}$, the MDA level is slightly higher compared to the untreated group, the mean values being of 1.18 and 1.03 times higher $(0.778 \pm 0.029 \mathrm{nmol} / \mathrm{mg}$ protein, respectively $0.684 \pm 0.038 \mathrm{nmol} / \mathrm{mg}$ protein).

In explaining the results, the limit of the dosage method must be taken into account, in the sense that, besides the malonic aldehyde generated as a result of lipid peroxidation, there are a number of other biological molecules that can interfere with the thiobarbituric acid used to dosing this cell marker, their concentration, largely depending, on the nutritional state that influences intracellular levels of polyunsaturated fatty acids and radical scavengers $[4,52]$.

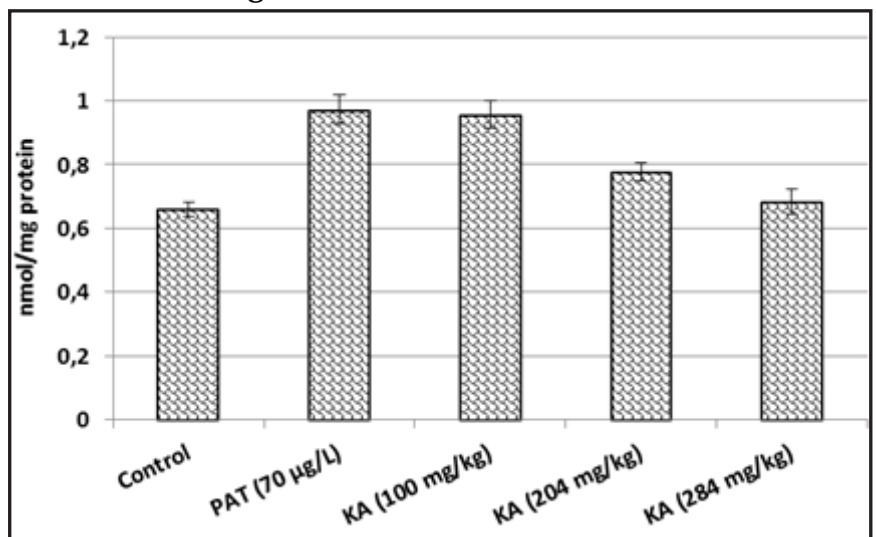

Fig. 5. MDA concentration in Danio rerio treated with PAT and KA

It seems that KA can induces macrophages activation by increasing ROS production without cytotoxicity [32], due to high oxygen consumption and reduced antioxidant capacity, the brain being sensitive to oxidative stress that has a direct influence on the occurrence of neurodegenerative diseases [53-55]. Literature data has not clearly demonstrated the existence of a direct connection between PAT and neurodegenerative diseases, yet, highlighting the neurotoxic effects of other mycotoxins on animal cells $[56,57]$.

That is why another objective of our study was to determine the influence that KA and PAT have on the memory and anxious behavior in Danio rerio.

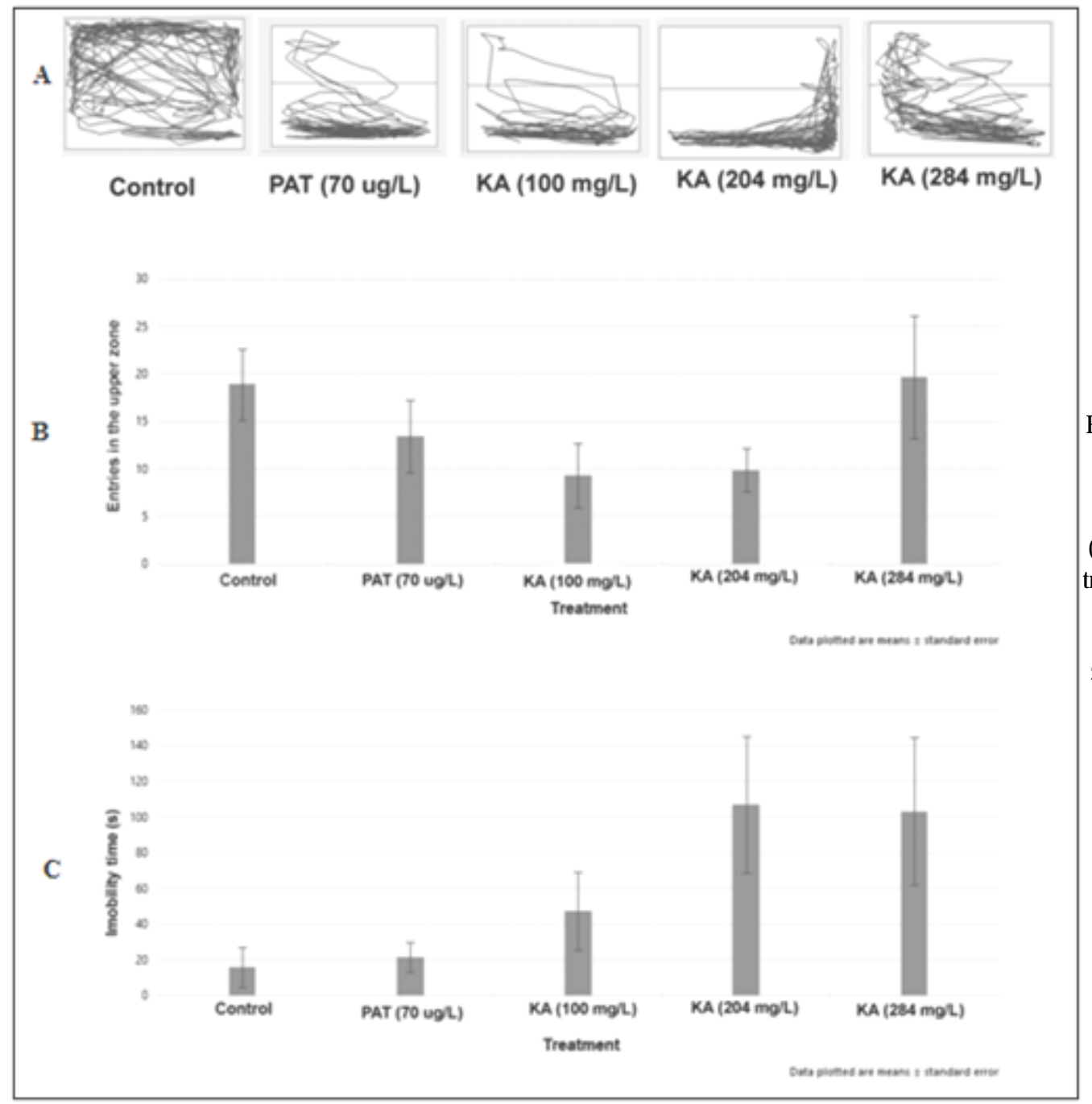

Fig. 6. Effects of patulin (PAT, 70 $\mu \mathrm{g} / \mathrm{L})$ and kojic acid (KA, 100 $\mathrm{mg} / \mathrm{L}, 204 \mathrm{mg} / \mathrm{L}$ and $284 \mathrm{mg} / \mathrm{L}$ ) on the behavioral parameters (A - Representative locomotion tracking patterns of control, PAT; $B$ - entries in the upper zone; C - immobility time - s) in zebrafish submitted to a novel tank diving test. Data are expressed as mean \pm S.E.M. (one-way ANOVA, $n=20$ ) 


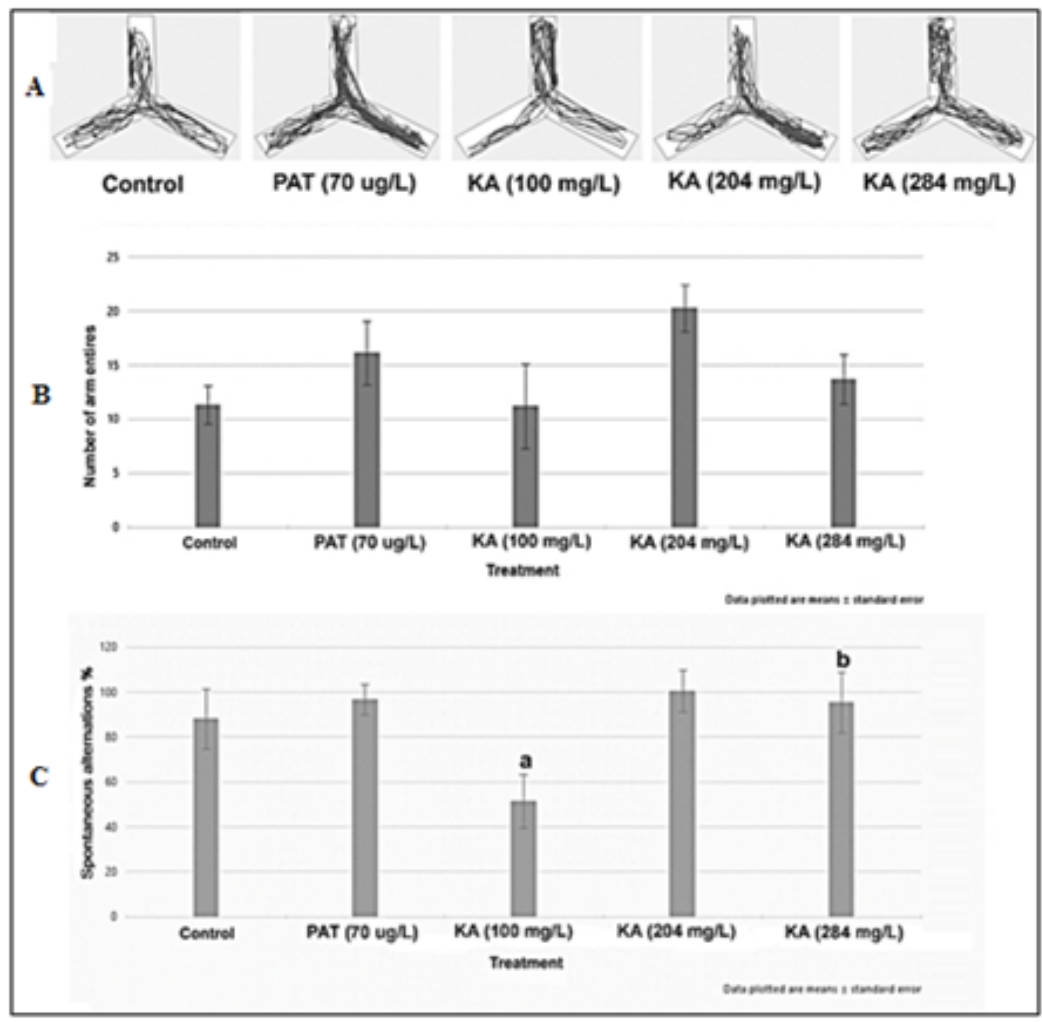

Fig. 7. Effects of patulin (PAT, $70 \mu \mathrm{g} / \mathrm{L}$ ) and kojic acid (KA, $100 \mathrm{mg} / \mathrm{L}, 204 \mathrm{mg} / \mathrm{L}$, and $284 \mathrm{mg} / \mathrm{L}$ ) on the behavioral parameters ( $A$ - Representative locomotion tracking patterns of control; $B$ - number of arm entries; C- spontaneous alternations $\%$, ) in zebrafish submitted to $Y$-maze test. Data are expressed as mean \pm S.E.M. (one-way ANOVA, $n=20$ ). For Tukey's posthoc analyses: a: PAT (70 70 $\mu \mathrm{g} / \mathrm{L})$ vs. KA (100 mg/L): $p<0.001$ and b: KA (204 $\mathrm{mg} / \mathrm{L})$ vs. $K A(284 \mathrm{mg} / \mathrm{L}): p<0.01$

As shown in figure $6 \mathrm{~A}$, NTT tracking locomotor pattern of the control group was demonstrated by regular swimming all over the tank while this pattern was attenuated by PAT and KA administration in a dosedependent manner. In figure 6B, administrations of PAT decrease the number of entries in the upper zone of the tank and slowly increase the immobility time (fig. $6 \mathrm{C}$ ). Additionally, administration of the KA decreased the number of entries in the upper zone of the tank, especially at the doses of 100 and $204 \mathrm{mg} / \mathrm{L}$, whereas the immobility time increased following administration of the KA especially at the doses of 204 and $284 \mathrm{mg} / \mathrm{L}$.

As can be seen in Fig. 7B, administration of PAT increased the locomotory activity as evidenced by the number of arm entries while the administration of KA induced a variation of locomotor activity near the level of the control group. Consequently, PAT increased the spontaneous alternations percentage, while a decreased of the percentage of the spontaneous alternation at the low dose of KA was evidenced (fig. 7C). In figure 7A, Y-maze tracking locomotor pattern of the control group was demonstrated by regular swimming all over the tank while this pattern was increased by PAT and KA administration in high doses.

Our results demonstrated that fish exposed to KA remain in the bottom zone of the tank, demonstration anxiogenic profile as compared to PAT administration. However, this effect could be attributed to hypo-locomotion as evaluated byan increase in the immobility time in the tank. In contrast, both PAT and KA administration, especially in the high doses, stimulated the memory formation, as evidenced by an increased percentage of the spontaneous alternation in the Y-maze. Our results are in line with previous reports, concerning the neuroprotective effects of the manganese complexes of KA [58].

\section{Conclusions}

The analysis of the experimental results on the influence of PAT and KA mycotoxins on memory, anxious behavior and oxidative stress in Danio rerio allowed us to formulate the following general conclusions:
-If under cellular homeostasis, ROS production is counterbalanced by their rate of elimination, in the event of disturbance due to the harmful effect of mycotoxins on cells, ROS accumulates in concentrations that cannot be controlled by common protective cellular mechanisms.

-Applying mycotoxins treatment resulted in the accumulation of high concentrations of ROS, which could not be kept under the control of endogenous antioxidants and led to the induction of oxidative stress and, consequently, a high level of lipid peroxidation, the MDA concentration being clearly superior, and GPX and CAT activity was lower in the samples treated with PAT and KA compared to the reference batch.

-The activity of antioxidant enzymes (GPX and CAT), but also the MDA concentration were decisively influenced by the agent applied, but also by its concentration in the environment, the differences between the experimental variants and the reference group, pointing out that at moderate concentrations mycotoxins, animal organisms are able to increase the production of antioxidantenzymes to counteract the excess of generated ROS.

-Both PAT and KA induced significant effects on the nervous system activity by slowly improving memory and enhance of anxiety-like behavior.

\section{References}

1.LIU, B.H., YU, F.Y., WU, T.S., LI, S.Y., SU, M.C., WANG, M.C., SHIH, S.M., Toxicology and Applied Pharmacology, 191, 2003, p. 255.

2.J ESTOI, M., Critical Reviews in Food Science and Nutrition, 48, 2008, p. 21.

3.WU, T.S., LIAO, Y.C., YU, F.Y., CHANG, C.H., LIU, B.H., Toxicology Letters, 183, 2008, p.105.

4.FERRER, E., JUAN-GARCÍA, A., FONT, G., RUIZ, M.J., Toxicology in Vitro, 23, 2009, p. 1504.

5.PAL, S., SINGH, N., ANSARI, K.M., Toxicology Research, 6, 2017, p. 764

6.SAXENA, N., ANSARI, K.M., KUMAR, R., CHAUDHARI, B.P., DWIVEDI, P.D., DAS, M., Toxicol. Appl. Pharmacol., 257, 2011, p. 264.

7.DRUSCH, S., RAGAB, W., J. Food Prot., 66, 2003, p. 1514.

8.TANGNI, E.K., THEYS, R., MIGNOLET, E., MAUDOUX, M., MICHELET, J.Y., LARONDELLE, Y., Food Addit. Contam., 20, 2003, p. 482. 
9.JACKSON, L.S., BEACHAM-BOWDEN, T., KELLER, S.E., ADHIKARI, C., TAYLOR, K.T., CHIRTEL, S.J., MERKEL, R.I., J. Food Prot., 66, 2003, p. 618

10.MAHFOUD, R., MARESCA, M., GARMY, N., FANTINI, J., Toxicol. Appl. Pharmacol., 181, 2002, p. 209.

11.ALVES, I., OLIVEIRA, N. G., LAIRES, A., RODRIGUES, A. S., RUEFF, J., Mutagenesis, 15, 2000, p. 229.

12.SHARMA, P., SHARMA, S., PATIAL, V., SINGH, D., PADWAD, Y.S., Clinical Queries: nephrology, 3, 2014, p. 97.

13.HEUSSNER, A.H., DIETRICH, D.R., O'BRIEN, E., Toxicology In Vitro, 20, 2006, p. 332.

14.SMITH, E.E., DUFFUS, E.A., SMALL, M.H., Arch. Environ. Contam. Toxicol., 25, 1993, p. 267.

15.LIU, B.H., WU, T.S., YU, F.Y., SU, C.C., Toxicology Science, 95, 2007, p. 340.

16.DOI, K., UETSUKA, K., J. Toxicol. Pathol., 27, 2014, p. 1.

17.PUEL, O., GALTIER, P., OSWALD, I., Toxin, 2, 2010, p. 613.

18.ZOUAOUI, N., MALLEBRERA, B., BERRADA, H., ABID-ESSEFI, S., BACHA, H., RUIZ, M.J. ., Food and Chemical Toxicology, 89, 2016, p. 92. 19.FLIEGE, R., METZLER, M., Chem. Res. Toxicol., 13, 2000, p. 363. 20.PFEIFFER, E., GROSS, K., METZLER, M., Carcinogenesis, 19, 1998, p. 1313.

21.PFEIFFER, E., DIWALD, T.T., METZLER, M., Mol. Nutr. Food Res., 49, 2005, p. 329.

22.YANG, G., ZHONG, L., JIANG, L., GENG, C., CAO, J., SUN, X., LIU, X., CHEN, M., MA, Y., Phytother. Res., 25, 2011, p. 1480.

23.DE MELO, F.T., DE OLIVEIRA, I.M., GREGGIO, S., DACOSTA, J.C., GUECHEVA, T.N., SAFFI, J ., HENRIQUES, J.A., ROSA, R.M., Food Chem. Toxicol.: Int. J. Published Br. Ind. Biol. Res. Assoc., 50, 2012, p. 3548. 24.PAPP, G., HORVATH, E., MIKE, N., GAZDAG, Z., BELAGYI, J., GYONGYI, Z., BANFALVI, G., HORNOK, L., PESTI, M., Food Chem. Toxicol.: Int. J. Published Br. Ind. Biol. Res. Assoc., 50, 2012, p. 3792. 25. SONG, E., XIA, X., SU, C., DONG, W., XIAN, Y., WANG, W., SONG, Y., Food and Chemical Toxicology, 71, 2014, p. 122.

26. BURDOCK, G.A., SONI, M.G., CARABIN, I.G., Regul. Toxicol. Pharm., 33, 2000, p. 80.

27. SOLANO, F., BRIGANTI, S., PICARDO, M., GHANEM, G., Pigment Cell Res., 19, 2006, p. 550.

28. CHOI, H., KIM, K., HAN, J., CHOI, H., JIN, S. H., LEE, E. K., SHIN, D. W., LEE, T.R., LEE, A.Y., NOH, M., J ournal of Dermatological Science, 66, 2012, p. 207.

29. LEI, T.C., VIRADOR, V.M., VIEIRA, W.D., HEARING, V.J., Anal Biochem., 305, 2002, p. 260.

30. MOTO, M., MORI, T., OKAMURA, M., KASHIDA, Y., MITSUMORI, K., Arch. Toxicol., 80, 2006, p. 299.

31. TAMURA, T., MITSUMORI, K., TOTSUKA, Y., WAKABAYASHI, K., KIDO, R., KASAI, H., NASU, M., HIROSE, M., Toxicology, 222, 2006, p. 213.

32. RODRIGUES, A.P.D., CARVALHO, A.S.C., SANTOS, A.S., ALVES, C.N., DO NASCIMENTO, J.L.M., SILVA, E.O., Cell Biol. Int., 35, 2011, p. 335. 33. RODRIGUES, A.P.D., FARIAS, L.H.S., CARVALHO, A.S.C., SANTOS, A.S., DO NASCIMENTO, J.L.M., SILVA, E.O., PLoS One, 9, 2014, p. 1. 34. DA COSTA, J.P., RODRIGUES, A.P., FARIAS, L.H., FRADE, P.C., DA SILVA, B.J.M., DO NASCIMENTO, J. L., SILVA, E., Biomedicine \& Pharmacotherapy, 101, 2018, p. 100.

35. DOBRIAN, A.D., DAVIES M.J., SCHRIVER S.D., LAUTERIO T.J., PREWITT R.L., Hypertension, 37, 2001, p. 554.
36. DUMITRU, G., TODIRASCU-CIORNEA, E., HRITCU, L., SANDU, I.G., Rev. Chim. (Bucharest), 69, no. 5, 2018, p. 1194.

37. DUMITRU, G., DIRVARIU, L., BARBACARIU, C.A., MIRON, I., SANDU, I., TODIRASCU-CIORNEA, E., Rev. Chim. (Bucharest), 69, no. 11, 2018, p. 4046.

38. DUMITRU, G., ABIDAR, S., NHIRI, M., HRITCU, L., BOIANGIU, R.S., SANDU, I., TODIRASCU-CIORNEA, E., Rev. Chim. (Bucharest), 69, no. 12, 2018, p. 3545.

39. BENCAN, Z., SLEDGE, D., LEVIN, E.D., Pharmacology Biochemistry and Behavior, 94, 2009, p. 75.

40. POSTU, P.A., NOUMEDEM, J.A.K., CIOANCA, O., HANCIANU, M., MIHASAN, M., CIORPAC, M., GORGAN, D.L., PETRE, B.A., HRITCU, L., Journal of Cellular and Molecular Medicine, 22, 2018, p. 111.

41. COGNATO, G.D.P., BORTOLOTTO, J.W., BLAZINA, A.R., CHRISTOFF, R.R., LARA, D.R., VIANNA, M.R., BONAN, C.D., Neurobiol Learn Mem, 98, 2012, p. 321.

42. AMATRUDA, J.F., SHEPARD, J.L., STERN, H.M., ZON, L.I., Cancer Cell., 1, 2002, p. 229.

43. LAN, C.C., LEONG, I.U., LAl, D., LOVE, D.R., Methods Cell Biol., 105, 2011, p. 419.

44. ADHIKARI, M., NEGI, B., KAUSHIK, N., ADHIKARI, A., ALKHEDHAIRY, A., KAUSHIK, N.K., CHOI, E.H., Oncotarget, 8, no. 20, 2017, p. 33933.

45. ZYCHOWSKI, K.E., HOFFMANN, A.R., LY, H.J., POHLENZ, C., BUENTELLO, A., ROMOSER, A., GATLIN, D.M., PHILLIPS, T.D., Toxins, 5, 2013, p. 1555.

46. ANATER, A., MANYES, L., MECA, G., FERRER, E., LUCIANO, F.B., PIMPÃO, C.T., FONT, G., Aquaculture, 451, 2016, p. 1.

47. ABID-ESSEFI, S., OUANES, Z., HASEN, W., BAUDRIMONT, I., CREPPY, E.E., BACHA, H., Toxicology In Vitro, 18, 2004, p. 467.

48. OMAR, H.E.D., Mycotoxins-Induced Oxidative Stress and Disease, Chapter 3, in: Mycotoxin and Food Safety in Developing Countries, Intech, 2013.

49. ZHANG, B., PENG, X., LI, G., XU, Y., XIA, X., WANG, W., Toxicon, 94, 2015, p. 1.

50. AYED BOUSSEMA, I., ABASSI, H., BOUAZIZ, C., HLIMA, W.B., AYED, Y., BACHA, H., Environ. Toxicol., 28, 2013, p. 299.

51. HOU, Y.J., ZHAO, Y.Y., XIONG, B., CUI, X.S., KIM, N.H., XU, Y.X., SUN, S.C., 2013, PLOS ONE, 8, no. 3, p. e60374.

52. KLARIC, M.S., PEPELJ NJ AK, S., DOMIJ AN, A.-M., PETRIK, J., Basic and Clinical Pharmacology and Toxicology, 100, 2006, p. 157.

53. PIMENTEL, C., BATISTA-NASCIMENTO, L., RODRIGUES-POUSADA, C., MENEZES, R.A., Oxid. Med. Cell Longev., 2012, 2012, ID number 132146.

54. CUI, K., LUO, X., XU, K., VEN MURTHY, M.R., Prog. Neuropsychopharmacol. Biol. Psychiatry, 28, 2004, p. 771.

55. NONGMAITHEM, R., LODHI, M.S., SAMAL, P.K., DHYANI, P.P., SHARMA, S., International J ournal of Conservation Science, 7, no. 2, 2016, p. 523.

56. ZHANG, X., BOESCH-SAADATMANDI, C., LOU, Y., WOLFFRAM, S., HUEBBE, P., RIMBACH, G., Genes Nutr., 4, 2009, p. 41.

57. OSUCHOWSKI, M.F., EDWARDS, G.L., SHARMA, R.P., Neurotoxicology, 26, 2005, p. 211.

58. VAJRAGUPTA, O., BOONCHOONG, P., SUMANONT, Y., WATANABE, H., WONGKRAJANG, Y., KAMMASUD, N., Bioorganic \& Medicinal Chemistry, 11, 2003, p. 2329.

Manuscript received: 12.09 .2018 